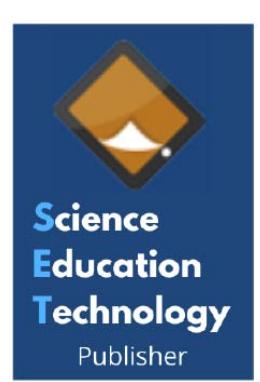

\title{
pH- Modified Solid Dispersions of Cefdinir for Dissolution Rate Enhancement: Formulation and Characterization
}

\author{
Raghad Al Nuss* and Hind El-Zein \\ Department of Pharmaceutics and Pharmaceutical Technology, Faculty of Pharmacy, Damascus University, \\ Damascus, Syria
}

\section{Article Info:}

Keywords:

Cefdinir,

$\mathrm{pH}_{\mathrm{M}}$-solid dispersion,

Alkalizer,

Dissolution rate enhancement.

Timeline:

Received: August 25, 2021

Accepted: October 21, 2021

Published: November 04, 2021

Citation: Al Nuss R. pH- Modified Solid

Dispersions of Cefdinir for Dissolution

Rate Enhancement: Formulation and

Characterization. J Pharm Nutr Sci

2021; 11: 101-115.

DOI: https://doi.org/10.29169/1927-5951.2021.11.13

\begin{abstract}
:
Objective: Cefdinir is a poorly- water-soluble drug, it belongs to Biopharmaceutical Classification System class IV, which shows that it may have limited therapeutic effects due to its low solubility and poor bioavailability. The aim of the present work was to design a $\mathrm{pH}$-modified solid dispersion $\left(\mathrm{pH}_{\mathrm{M}}-\mathrm{SD}\right)$ that can improve the dissolution rate of cefdinir and subsequently its bioavailability.

Materials and Methods: $\mathrm{pH}_{\mathrm{M}}$-SDs of cefdinir were prepared at different drug-to-carrier ratios by the spray-drying technique. The solid dispersions were investigated by dissolution studies at different $\mathrm{pH}$ media, drug release kinetics were studied, and their solid-state characterizations were performed by FTIR spectrophotometer, Scanning electron microscopy (SEM), Differential scanning calorimetry (DSC), and Powder Xray diffraction (PXRD).

Results: PVP- based and HPMC- based $\mathrm{pH}_{\mathrm{M}} \mathrm{SD}$ s exhibited a marked improvement in the dissolution behavior when compared with crystalline cefdinir powder, whereas Eudragit $\mathrm{L} 100$-based $\mathrm{pH}_{\mathrm{M}}$-SDs showed lower dissolution at $\mathrm{pH} 1.2$ and 4.5.

FTIR results may indicate a formation of a salt between cefdinir and the alkalizer. Solid-state characterization may indicate a change in crystallinity of cefdinir into an amorphous state. Mathematical modeling of in vitro dissolution data indicated the best fitting with Korsmeyer-Peppas model and the drug release kinetics primarily as Fickian diffusion.

Conclusion: According to these observations, $\mathrm{pH}_{\mathrm{M}}-\mathrm{SD}$ in the presence of an alkalizer for a poorly water-soluble acidic drug, cefdinir, appeared to be efficacious for enhancing its dissolution rate.
\end{abstract}




\section{INTRODUCTION}

Cefdinir is a third-generation oral cephalosporin antibiotic [1]. It belongs to BCS class IV, with low solubility resulting in low bioavailability of about $21 \%$ for capsules and $25 \%$ for suspension [2]. Its solubility is highly dependent on the $\mathrm{pH}$ of the media $[3,4]$.

In formulation development, weakly acidic or basic drugs pose a major challenge as the solubility depends significantly on the $\mathrm{pH}$ of the dissolution media. This gives rise to $\mathrm{pH}$-dependent drug release, as the formulation is exposed to different $\mathrm{pH}$ ranges in the gastrointestinal tract. This indicates a need to carry out formulation optimization for such drugs while developing them into a dosage form [5].

Several approaches have been investigated to improve the dissolution rate and bioavailability of Cefdinir, including nanosuspensions [6, 7], amorphization [8], cyclodextrin complexation [4, 9], self-emulsification [10], and solid dispersions (SDs) [11-16].

Among these approaches, the application of SDs is attracting increasing attention [11-16] but, notwithstanding the positive results in these researches, none of them was able to achieve a $\mathrm{pH}$ independent dissolution behavior which is important for improving the bioavailability of weakly acidic or basic drugs due to their exposure to different $\mathrm{pH}$ degrees along the gut after oral administration.

Besides that, the solubilization capacity of SDs has generally been limited by the carrier type, recrystallization, or spring-like precipitation upon exposure to an aqueous solution [17, 18]. To improve the solubilization capacity of SDs, extra agents were introduced [19]. The additives included surfactants [12], and $\mathrm{pH}$ modifiers $[20,21]$. Because cefdinir has a $\mathrm{pH}$ dependent solubility $[3,4]$ modulating the $\mathrm{pH}$ in solid dosage forms, which is the 'microenvironmental $\mathrm{pH}^{\prime}$ $\left(\mathrm{pH}_{\mathrm{M}}\right)$, seems to be a promising way to modify the release rate of cefdinir.

In this article, a poorly water-soluble weakly acidic drug (cefdinir) loaded $\mathrm{pH}_{\mathrm{M}}$-SDs were prepared using PVPK30 (Polyvinylpyrrolidone), HPMC 606 (hydroxypropyl methylcellulose), or Eudragit L100 (ethyl polymethacrylate) in different drug: polymer ratios (1:1, 1:2 w: w). The alkalizer $(\mathrm{NaOH})$ was selected as a $\mathrm{pH}-$ modifier based on solubility results. The $\mathrm{pH}_{\mathrm{M}}-\mathrm{SD}$ were prepared using the spray-drying technique. The Spraydrying technique was used because it is mainly aimed at generating amorphous materials and is the technique of choice for particle size reduction. We also assessed their physicochemical characteristics through an FTIR spectrophotometer, Scanning electron microscopy (SEM), Differential scanning calorimetry (DSC), and X-ray diffraction (PXRD). We have also studied in vitro release in media with different $\mathrm{pH}$.

\section{MATERIALS AND METHODS}

\subsection{Materials}

Cefdinir was obtained from (lupin Co. Ltd, India). PVPK30 was obtained from (Ashland Inc, America). Hydroxypropyl methylcellulose was purchased from (Shine-Etsu chemical Co. Ltd, Japan). Eudragit L100 was procured from (Evonik Industries, Germany). $\mathrm{NaOH}$ was obtained from (Carl Roth $\mathrm{Gmbh} \& \mathrm{Co} \circledast$, Germany). All other used reagents and solvents were of analytical grade and were used as received.

\subsection{Instruments}

- $\quad$ Mini spray dryer (Buchi-191) (Germany).

- UV-VIS Spectrophotometer (T80) from (PG, United Kingdom).

- Infrared spectrophotometer (FTIR) (Vector 22) from (Bruker, Germany).

- Differential Scanning calorimetry (DSC 131) from (Setaram, France).

- $\quad$ Powder X-ray diffraction device (PXRD) from (Bruker D8, West Germany).

- Dissolution apparatus (PTDT7) from (Pharmatest, Germany).

- $\quad$ Scanning electron microscopy (SEM, VEGA II LSH, TESCAN, Czech Republic).

- Hermle Z 200 A Centrifuge, Germany

\subsection{Solubility of Cefdinir and Screening for $\mathrm{pH}$ Modifiers}

The solubility of Cefdinir in various solvents $(\mathrm{pH} 1.2$ $\mathrm{HCl}$ buffer, $\mathrm{pH} 4.5$ acetate buffers, $\mathrm{pH} 6.8$ phosphate buffer, and distilled water), alkalizers ( $1 \% \mathrm{w} / \mathrm{v}$ solution of aqueous sodium hydroxide, potassium hydroxide, and sodium bicarbonate). Solubility measurements were performed in triplicate using the shake flask method [22]. Excess cefdinir (100) mg was added to 10 
Table 1: The Composition of the Prepared $\mathrm{pH}_{\mathrm{M}}$ - SDs Systems of Cefdinir

\begin{tabular}{|c|c|c|c|c|c|}
\hline Code & Cefdinir (mg) & $\begin{array}{c}\mathrm{NaOH} \\
(\mathrm{mg})\end{array}$ & PVP K30 (mg) & $\begin{array}{l}\text { HPMC } 606 \\
(\mathrm{mg})\end{array}$ & Eudragit L100 (mg) \\
\hline $\mathrm{F} 1$ & 300 & 30.35 & 300 & 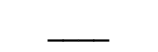 & $\underline{-}$ \\
\hline $\mathrm{F} 2$ & 300 & 30.35 & 600 & $\underline{-}$ & $\underline{-}$ \\
\hline F3 & 300 & 30.35 & $\underline{-}$ & 300 & 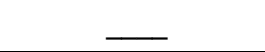 \\
\hline $\mathrm{F} 4$ & 300 & 30.35 & - & 600 & 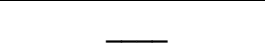 \\
\hline F5 & 300 & 30.35 & $\underline{-}$ & 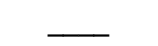 & 300 \\
\hline F6 & 300 & 30.35 & 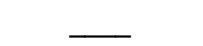 & 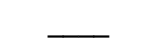 & 600 \\
\hline
\end{tabular}

$\mathrm{mL}$ of each solution. The samples were subjected to a constant shaking for 72 hours, then centrifuged (5000 x g, 30 min, using Hermle Z 200 A Centrifuge, Germany), filtered ( 0.45 micron), diluted, and analyzed by UV-VIS spectrophotometer (PG Instruments T80 UV/VIS spectrophotometer, United Kingdom) at $287 \mathrm{~nm}$ [23, 24].

\subsection{Manufacturing of $\mathrm{pH}_{\mathrm{M}}-\mathrm{SDs}$}

The $\mathrm{pH}_{\mathrm{M}}-\mathrm{SDs}$ containing Cefdinir were prepared by a spray drying technique. The detailed compositions of SDs are shown in Table 1.

Briefly, cefdinir was dispersed in deionized water, then PVP-K30 (or HPMC 606, or Eudragit L100) solution was gradually added to cefdinir suspension with a continuous stirring to reach the desired weight ratio (1:1, or $1: 2 \mathrm{w}: \mathrm{w}$, drug: polymer). $\mathrm{NaOH}(0.1 \mathrm{~N})$ was added dropwise until the $\mathrm{pH}$ reaches 7 (the solutions become clear after the addition of $\mathrm{NaOH}$ in PVP-K30 and HPMC- based formulation, which indicates the complete dissolution of cefdinir before spraying).

The resulting solutions were immediately dried using Buchi mini spray dryer B-191, Germany.

The following conditions were used: inlet temperature $160{ }^{\circ} \mathrm{C}$, outlet temperature $83 \pm 6{ }^{\circ} \mathrm{C}$, airflow rate 600 $\mathrm{l} / \mathrm{h}$, and pump rate $5.3 \pm 0.2 \mathrm{ml} / \mathrm{min}$, Spray nozzle 0.7 $\mathrm{mm}$, Aspirator $80 \%$.

\subsection{Process Yield and Drug Content Estimation}

Amorphous solid dispersions obtained from the spray drying were weighed (Weighing Analytical Balance Sartorius M2P, Germany). Yield the percentage was calculated by Eq. (1) [25].

Yield $(\%)=\frac{\text { Weight of amorphous solid dispersion }}{\text { Initial weight of drug and polymer }} \times 100$
The total drug content in the sample was estimated by dissolving a predetermined amount of solid dispersion in a $6.8 \mathrm{pH}$ phosphate buffer and was sonicated for 15 $\min$.

The solution was suitably diluted with freshly prepared PBS $6.8 \mathrm{pH}$ and was assayed by a UV-VIS spectrophotometer (T80 PG Uv/Vis spectrophotometer, United gangdom) for drug content at $287 \mathrm{~nm}[23,24]$ using Eq. (2) [26]. Each experiment has been repeated three times. Before adopting this analytical method, its selectivity for the drug was confirmed by conducting a spectroscopic scan of a solution of the used polymers in phosphate buffer with the same concentrations used in the formulations.

Percent drug content $=\frac{\text { Practical content }}{\text { Theoritical content }} \times 100$

\subsection{Characterization of the SDs}

\subsubsection{Fourier Transform Infrared Spectroscopy (FTIR)}

FTIR spectra of samples were recorded using a Bruker Vector 22 spectrophotometer. Samples were compressed into $\mathrm{KBr}$ disks in a hydraulic press to prepare sample- $\mathrm{KBr}$-blends. $\mathrm{KBr}$ pellets were characterized from 400 to $4000 \mathrm{~cm}^{-1}$ and with a resolution of $2 \mathrm{~cm}^{-1}$ [24].

\subsubsection{Scanning Electron Microscope (SEM)}

The morphology and particle size of pure cefdinir and the prepared $\mathrm{pH}_{\mathrm{M}}-\mathrm{SDs}$ were observed through scanning electron microscopy (SEM, VEGA II LSH, TESCAN, Czech Republic). Before SEM imaging, samples were coated with gold by a sputter coater. Approximately $1 \mathrm{mg}$ of each sample was placed onto a double-sided adhesive strip on a sample holder. SEM images were taken at $10,000 \times$ magnification. 


\subsubsection{Differential Scanning Calorimetry (DSC)}

The thermal properties of samples were characterized by the DSC instrument, DSC 131 (SETARAM, France). Each sample was accurately weighed (equivalently to 5 $\mathrm{mg}$ ) into an aluminium pan and heated in the range of $30-300{ }^{\circ} \mathrm{C}$, at a scanning rate of $10{ }^{\circ} \mathrm{C} / \mathrm{min}$ under nitrogen airflow of $50 \mathrm{~mL} / \mathrm{min}$ [24].

\subsubsection{Powder X-Ray Diffraction}

Powder X-ray diffraction patterns of cefdinir and the $\mathrm{pH}_{\mathrm{M}}$-SDs were obtained using Bruker's D8 Advance diffractometer (Karlsruhe, West Germany). PXRD patterns were recorded using Germanium monochromatic and $\mathrm{Cu}$ radiation with a nitrogen filter at a voltage of $50 \mathrm{KeV}$ and a current of $30 \mathrm{~mA}$. The samples were analyzed over the $2 \theta$ range of $(3-60)^{\circ}$ [24].

\subsection{Drug Release Studies}

Dissolution studies were carried out using the USP paddle method at $(37 \pm 0.2)^{\circ} \mathrm{C}$ in a Pharma test PT-DT7 dissolution tester (Germany) at $50 \mathrm{rpm}$ with $900 \mathrm{~mL}$ of $\mathrm{HCl}$ buffer ( $\mathrm{pH}$ 1.2), acetate buffer $(\mathrm{pH} 4.5)$, and phosphate buffer ( $\mathrm{pH}$ 6.8) fluids as dissolution media [15]. The $\mathrm{pH}_{\mathrm{M}}-\mathrm{SDs}$ (equivalent to $300 \mathrm{mg}$ of cefdinir) and pure drug were dispersed in the dissolution media, and at predefined intervals, $5-\mathrm{ml}$ samples were withdrawn at $(2,5,10,15,20,30,45$, and 60$)$ minutes, filtered through $0.45 \mu \mathrm{m}$ syringe filter, and assayed via UV-VIS spectrophotometer (T80 PG, United Kingdom) for released drug at $\lambda_{\max }(280,286$, and $287 \mathrm{~nm})$ for $\mathrm{HCl}$ buffer $\mathrm{pH}=1.2$, acetate buffer $\mathrm{pH}=4.5$, and phosphate buffer $\mathrm{pH}=6.8$, respectively. An equivalent amount of release medium was supplemented to keep the volume constant. Each experiment was repeated six times.

\subsection{Statistical Analysis of the Drug Release Profile}

All the results were expressed as mean values \pm standard deviation. The difference between percentages (fractions) of released cefdinir at each time interval from the pure drug, and prepared $\mathrm{pH}_{\mathrm{M}^{-}}$ SDs were statistically evaluated by using a two-tailed Student's t-test. All data analysis was performed using the Microsoft Excel 2019 software. A confidence limit of $p<0.05$ was fixed for the interpretation of the results.

Percent dissolution efficiency (\%DE) was also computed to compare the relative performance of various carriers in solid dispersion formulations [27].
The magnitude of \%DE at $10 \mathrm{~min}(\% \mathrm{DE} 10 \mathrm{~min})$ and 30 min (\%DE30 min) for each formulation were computed as the percent ratio of area under the dissolution curve up to the time, $t$, to that of the area of the rectangle described by $100 \%$ dissolution at the same time [28]

$\% D E=\left(\frac{\int_{0}^{t} y \cdot d t}{y 100 t}\right) 100$

\subsection{Mathematical Modeling of Release Kinetics}

The in vitro drug release data were fitted to various release kinetic models [29-31] viz. first-order, Higuchi, Hixson-Crowell cube root, Korsmeyer-Peppas, and zero-order model employing the following set of equations:

First-order model

$F=F_{\max } *\left[1-e^{(-k 1 . t)}\right]$

Zero-order kinetic model

$\mathrm{F}=\mathrm{F}_{0}+\mathrm{k}_{0} \cdot \mathrm{t}$

Higuchi model

$\mathrm{F}=\mathrm{F}_{0}+\mathrm{k}_{\mathrm{H}} \cdot \mathrm{t}^{0.5}$

Hixson-Crowell cube root model

$F=100 *\left[1-\left(1-k_{H C}{ }^{*} t\right)^{\wedge} 3\right]$

Korsmeyer-Peppas model

$F=k_{K P}^{*} t^{n}$

where $\mathrm{F}$ is the fraction (\%) of drug released in time $\mathrm{t}, \mathrm{F}_{0}$ is the initial fraction of the drug in the solution resulting from a burst release. Various other terms viz. $k_{\mathrm{KP}}, \mathrm{k}_{\mathrm{o}}$, $\mathrm{k}_{1}, \mathrm{k}_{\mathrm{HC}}$, and $\mathrm{K}_{\mathrm{H}}$ refer to the release kinetic constants obtained from the linear curves of KorsemeyerPeppas, zero-order, first-order, Hixson-Crowell cube root law, and Higuchi model, respectively. Model fitting using Eqs. (4)-(8) was accomplished by using DDSolver software (add-in program for Microsoft Excel) [32].

\section{RESULTS AND DISCUSSION}

\subsection{Solubility Results}

As expected for a weakly acid, cefdinir solubility highly depends on the $\mathrm{pH}$ of the media "Figure 2". 
<smiles>C=CC1=C(C(=O)O)N2C(=O)[C@H](NC(=O)/C(=N\O)c3csc(N)n3)[C@H]2SC1</smiles>

Figure 1: Chemical structure of cefdinir.

Cefdinir can be classified as practically insoluble in water $(0.47) \mathrm{mg} / \mathrm{mL}$. The solubility of cefdinir "Figure 2" was sharply increased over $\mathrm{pH} 4.5$. This is because Cefdinir has three ionizable groups with the following pKa values: $-\mathrm{COOH}$ group of cephem moiety $(\mathrm{pKa}=$ 1.9), $-\mathrm{NH} 2$ group of the aminothiazole moiety ( $\mathrm{pKa}=$ 3.3 ), and $=\mathrm{N}-\mathrm{OH}$ group of the oxime moiety ( $\mathrm{pKa}=$ 9.9) [33]. According to the Henderson-Hasselbalch equation, the $-\mathrm{COOH}$ group of the cephem moiety (pKa

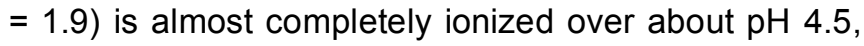
likely causing the observed increased aqueous solubility of cefdinir over about $\mathrm{pH}$ 4.5. The $\mathrm{pH}$ dependent solubility (as shown in "Figure 2") indicated that a neutral to basic $\mathrm{pH}$ environment might facilitate drug dissolving. Consequently, alkalizers were chosen as the $\mathrm{pH}$ modifiers; and to choose the best alkalizer, Cefdinir solubility in $1 \% \mathrm{w} / \mathrm{v}$ aqueous solution of different alkalizers (i.e. $1 \% \mathrm{w} / \mathrm{v}$ solution of aqueous sodium hydroxide, potassium hydroxide, and sodium bicarbonate) was studied. The solubility of Cefdinir in various solvents, alkalizer solutions were presented in Figure 2. Based on the solubility, sodium hydroxide was selected for the development of the $\mathrm{pH}_{\mathrm{M}}-\mathrm{SDs}$. The Spray-drying technique was used because it is mainly aimed at generating amorphous materials and is the technique of choice for particle size reduction [19]. In order to avoid using organic solvents during the preparation process, sodium hydroxide $(\mathrm{NaOH})$ was used as an alkalizer to increase the solubility of cefdinir in the polymeric solutions.

\subsection{Process Yield and Drug Content Estimation}

Figure 3 shows the UV-VIS spectrophotometric scan of cefdinir solution and polymers solution. As we can see there was not any interference by polymers in UV analysis at $287 \mathrm{~nm}$. The process parameters and drug-

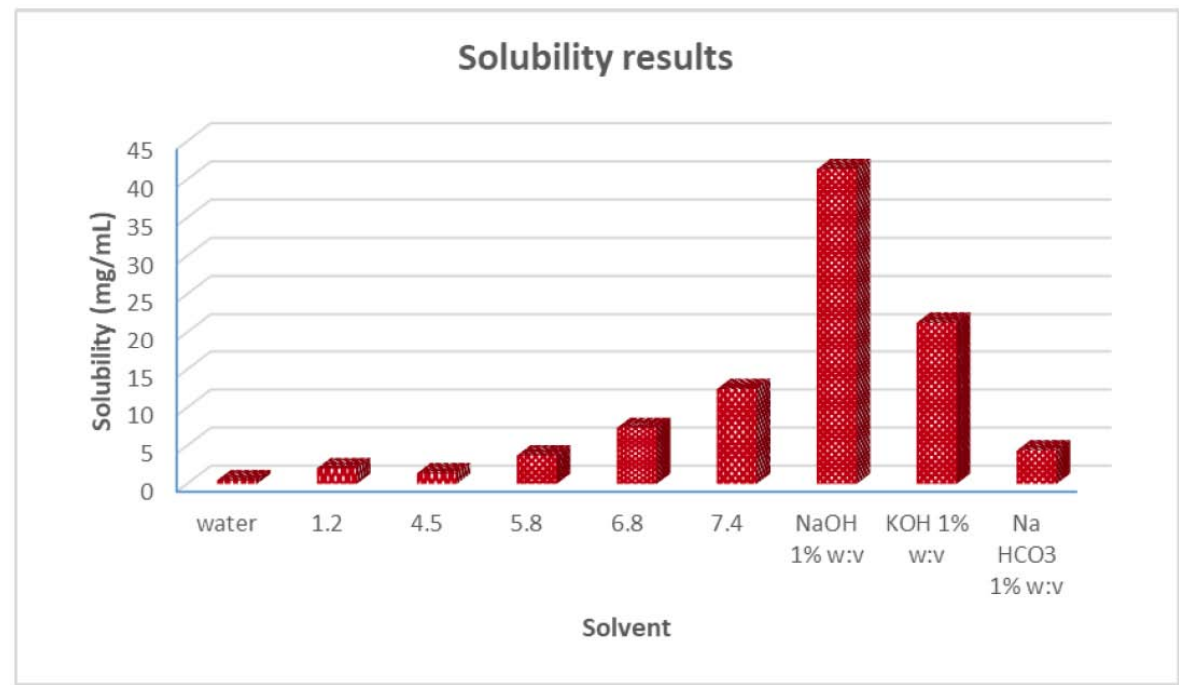

Figure 2: the $\mathrm{pH}$-dependent solubility of cefdinir.
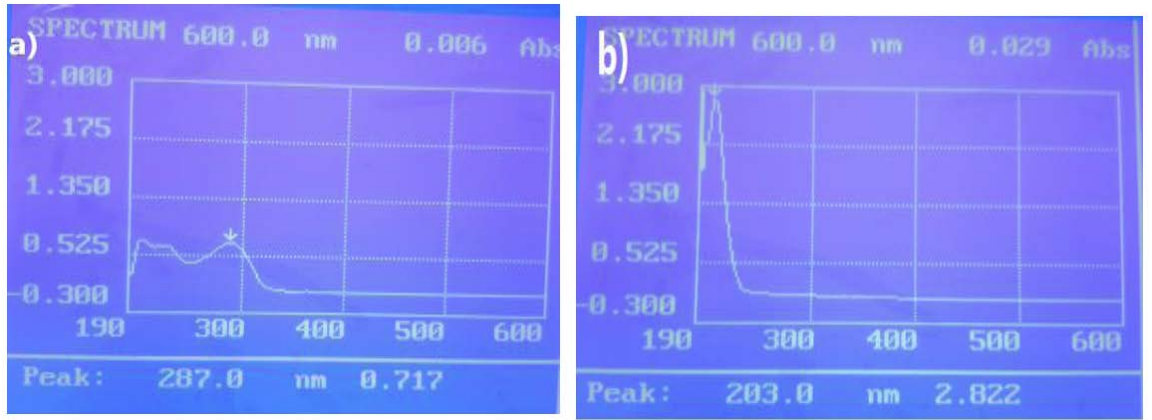

Figure 3: UV-VIS scan of a solution of a) Cefdinir, b) used polymers at the same concentration used in formulations F1 to F6. 
Table 2: Particle Characterizations, Process Yield and Drug Content of Prepared $\mathrm{pH}_{\mathrm{M}}-\mathrm{SDs}$

\begin{tabular}{|c|c|c|c|}
\hline Formulation code & Particle size $(\boldsymbol{\mu m}) \pm$ SD & Process yield $(\%)$ & Drug content $(\%)$ \\
\hline \hline F1 & $1.706 \pm 0.128$ & 80.55 & $96.083 \pm 1.325$ \\
\hline F2 & $1.493 \pm 0.172$ & 78.56 & $97.986 \pm 2.745$ \\
\hline F3 & $1.988 \pm 0.164$ & 50.93 & $99.628 \pm 2.867$ \\
\hline F4 & $1.869 \pm 0.124$ & 44.19 & $97.065 \pm 1.023$ \\
\hline F5 & $1.862 \pm 0.182$ & 75.67 & $100.312 \pm 4.031$ \\
\hline
\end{tabular}

carrier content load will influence the yield (\%) of the spray-dried product. The process yield and estimated drug content for each formula are shown in Table 2.

F3 and F4 showed lower yields, which could be due to the stickiness of the product [34]. Drug content results (Table 2) indicated that the formulation composition and preparing process had almost no effect on the drug content of the SDs $[35,36]$.

\subsection{Fourier Transform Infrared Spectroscopy (FTIR)}

"Figure 4a" shows the FTIR spectra of cefdinir, PVP$\mathrm{K} 30, \mathrm{~F} 1$, and F2. The FTIR spectra of HPMC, F3, and
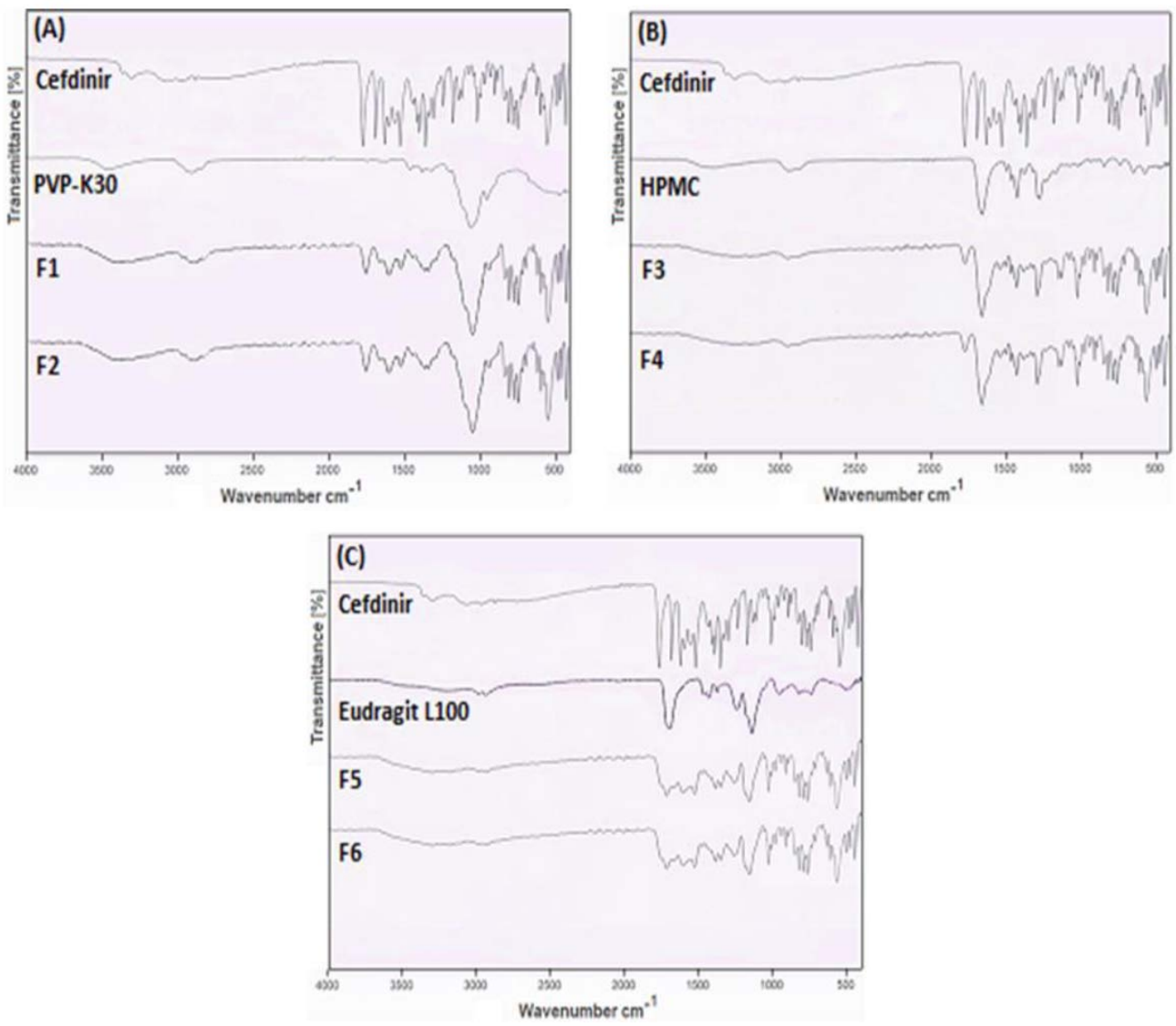

Figure 4: FTIR spectra of Cefdinir and different formulation.

F4 are shown in "Figure $\mathbf{4 b}$ ", whereas the FTIR spectra of Eudragit L100, F5, and F6 are present in "Figure $4 c "$.

FTIR spectrum of Cefdinir "Figure $\mathbf{4 a "}$ is characterized by principal absorption peaks at $3300 \mathrm{~cm}^{-1}(\mathrm{O}-\mathrm{H}$ stretch $\mathrm{COOH}$ ), $2978 \mathrm{~cm}^{-1}$ (C-H stretch cyclic), $2898 \mathrm{~cm}^{-1}$ (C-H stretch), $1781 \mathrm{~cm}^{-1}$ (C-O), $1763 \mathrm{~cm}^{-1}$ (co of $\beta$-lactam), $1667 \mathrm{~cm}^{-1}$ (C-C alkene), $1610 \mathrm{~cm}^{-1}$ (C-C aromatic), $1544 \mathrm{~cm}^{-1}$ (N-H bending), $1428 \mathrm{~cm}^{-1}$ (C-N stretch) and $656 \mathrm{~cm}^{-1}$ (C-S) [4]. The FTIR spectrum of pure PVP K30 (Figure 4a) produced a characteristic absorption band at $1658 \mathrm{~cm}^{-1}$. This can be attributed to the carbonyl group [37]. The very broadband at $3440 \mathrm{~cm}^{-1}$ 
indicates the presence of moisture, revealing the hygroscopic nature of PVP K30 [37]. In the FTIR spectrum of HPMC (Figure $\mathbf{4 b}$ ), the broad absorption band at $3456 \mathrm{~cm}^{-1}$ indicates the stretching frequency of the $-\mathrm{OH}$ groups. The bands at 2948 and $1065 \mathrm{~cm}^{-1}$ represent the stretching vibration of $\mathrm{C}-\mathrm{H}$ and $\mathrm{C}-\mathrm{O}$ bonds, respectively. The bending vibration of $-\mathrm{OH}$ groups on the HPMC appeared at $1419 \mathrm{~cm}^{-1}$ [38]. The spectrum of Eudragit L100 (Figure 4c) has a characteristic band of $\mathrm{OH}\left(3170 \mathrm{~cm}^{-1}\right), \mathrm{CH}$ Stretching Aromatic $\left(3067 \mathrm{~cm}^{-1}\right), \mathrm{CH}$ Stretching Aliphatic (2954 $\left.\mathrm{cm}^{-1}\right), \mathrm{C}=\mathrm{O}\left(1598 \mathrm{~cm}^{-1}\right)$ [39].

On the other hand, all $\mathrm{pH}_{\mathrm{M}} \mathrm{SD}$ S $(\mathrm{F} 1, \mathrm{~F} 2, \ldots . . \mathrm{F} 6)$ exhibit strong absorbance between 1650 and $1550 \mathrm{~cm}^{-1}(1614$ $\mathrm{cm}^{-1}$ for $\mathrm{pH}_{\mathrm{M}}-\mathrm{SD}$ s prepared with PVP-K30), (1654 $\mathrm{cm}^{-1}$ for $\mathrm{pH}_{\mathrm{M}^{-}} \mathrm{SD}$ s prepared with HPMC), (1561 $\mathrm{cm}^{-1}$ for $\mathrm{pH}_{\mathrm{M}^{-}}$ SDs prepared with eudragit L100). This strong absorbance may be attributed to the carboxylate group of cefdinir [40]. And the carbonyl peaks due to carboxylic acid interactions at 1710 and $1735 \mathrm{~cm}^{-1}$ are not seen in the spectra of the prepared formulations due to loss of proton [40]. FTIR data may indicate direct conversion from crystalline cefdinir to amorphous salt [40].

\subsection{Scanning Electron Microscope (SEM)}

SEM was used to compare the morphology and particle size of each formulation. SEM micrographs of pure cefdinir and its $\mathrm{pH}_{\mathrm{M}}-\mathrm{SDs}$ are shown in "Figure 5". Pure drug consisted of acicular shaped particles with a mean particle size $(2.413 \pm 1.29) \mu \mathrm{m}$. On the contrary, the solid dispersions appeared in the form of spherical particles and the original morphology of cefdinir disappeared which was supported by DSC, and PXRD. Particle sizes for prepared $\mathrm{pH}_{\mathrm{M}}-\mathrm{SD}$ are shown in Table 2.
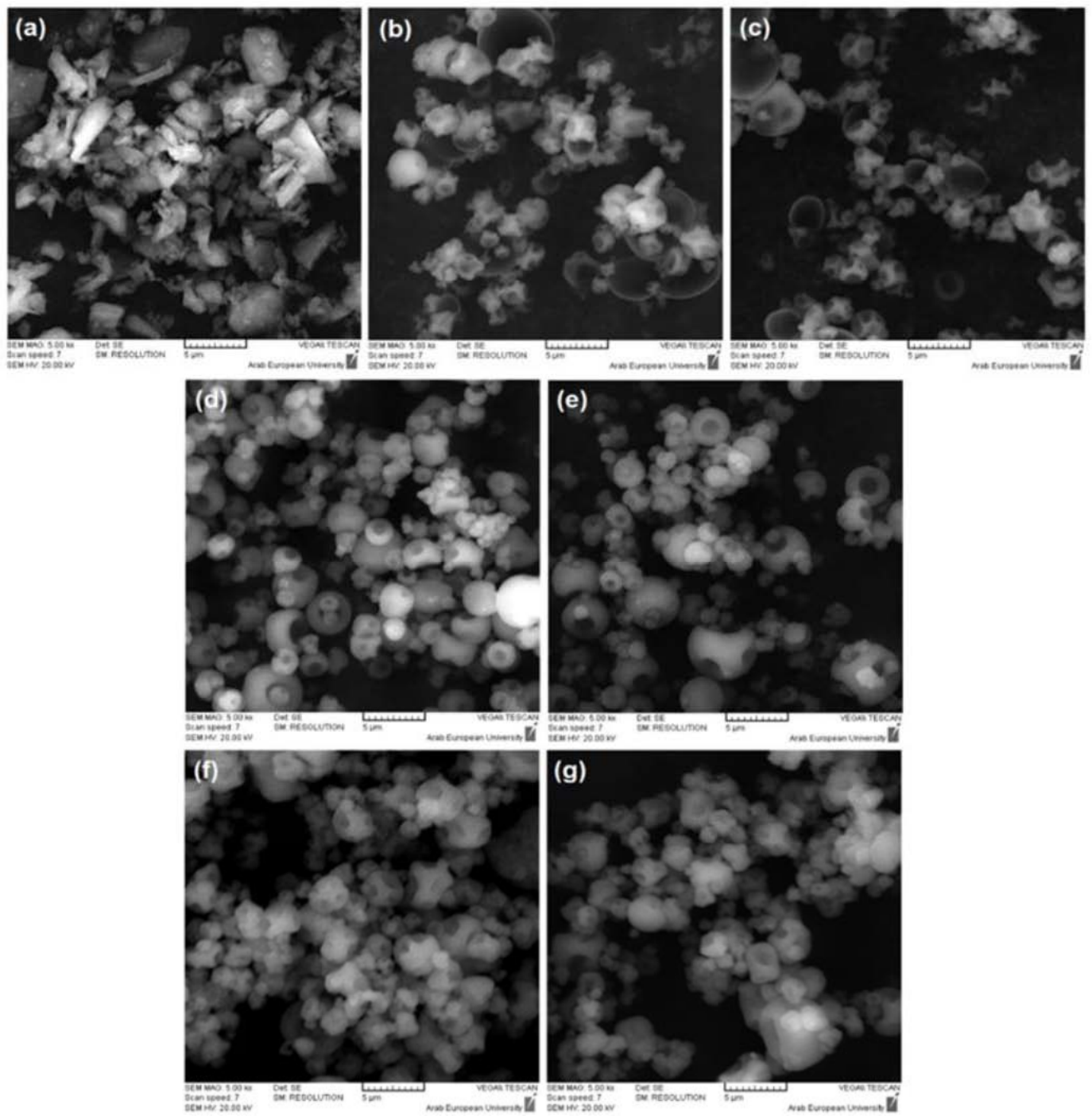

Figure 5: Scanning electron microscopy at magnification (X10,000) of a) pure cefdinir b) F1 c) F2 d) F3 e) F4 f) F5 g)F6. 


\subsection{Differential Scanning Calorimetry (DSC)}

The solid state of the drug in the $\mathrm{pH}_{\mathrm{M}}-\mathrm{SDs}$ was characterized by using DSC, and PXRD. The endotherm in the thermogram of pure cefdinir "Figure 6" at $60.35^{\circ} \mathrm{C}$ indicates the glass transition temperature of cefdinir [41] and the sharp exotherm at $227.33^{\circ} \mathrm{C}$ represents drug degradation [42]. These results were in good agreement with the reported DSC curve of cefdinir anhydrous [42]. DSC thermogram of PVP K30 reveals glass transition temperature at $175.43^{\circ} \mathrm{C}$, with the absence of any melting point peak "Figure. 7" [43, 44]. This result suggests an amorphous characteristic of PVP K30 [43]. Besides, a broad endotherm ranging from (48.08 to 99.51$)^{\circ} \mathrm{C}$ is observed in the thermogram of pure PVPK30 which was attributed to the water loss from the hygroscopic polymer upon heating [43]. The DSC thermogram of HPMC "Figure 8" shows no sharp endothermic peaks indicating no exact melting points [45]. A broad endothermic bend in the thermogram appears from (41.87 to 118.53$){ }^{\circ} \mathrm{C}$, which might be due to the volatilization of adsorbed water [46]. The thermogram of Eduragit L100 "Figure 9" showed two endothermic peaks. The first is a broad peak between (46.78 and 115.44$)^{\circ} \mathrm{C}$, which can be explained by the evaporation of the absorbed moisture [47]. The other

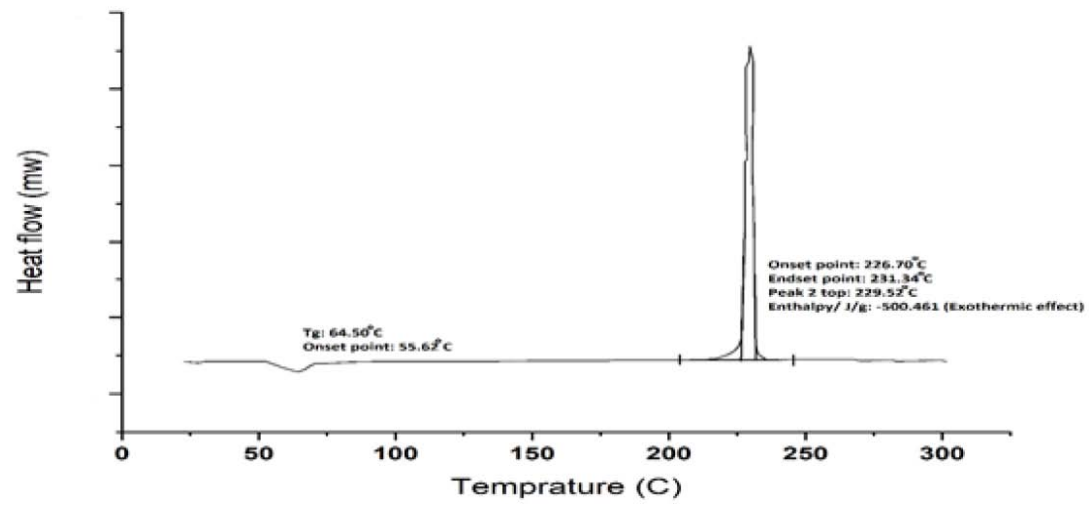

Figure 6: DSC thermograms of Cefdinir.

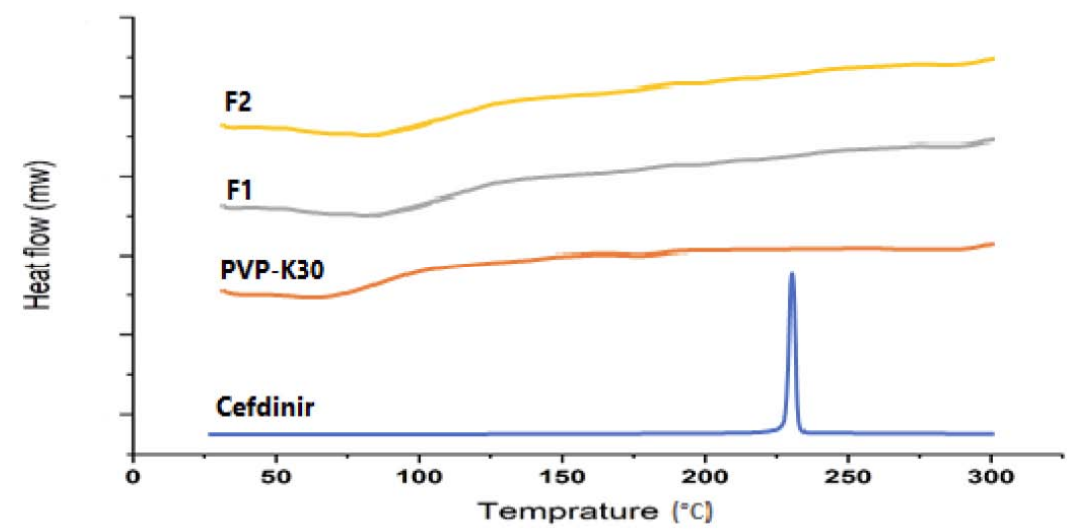

Figure 7: DSC thermograms of Cefdinir, PVP, F1, and F2.

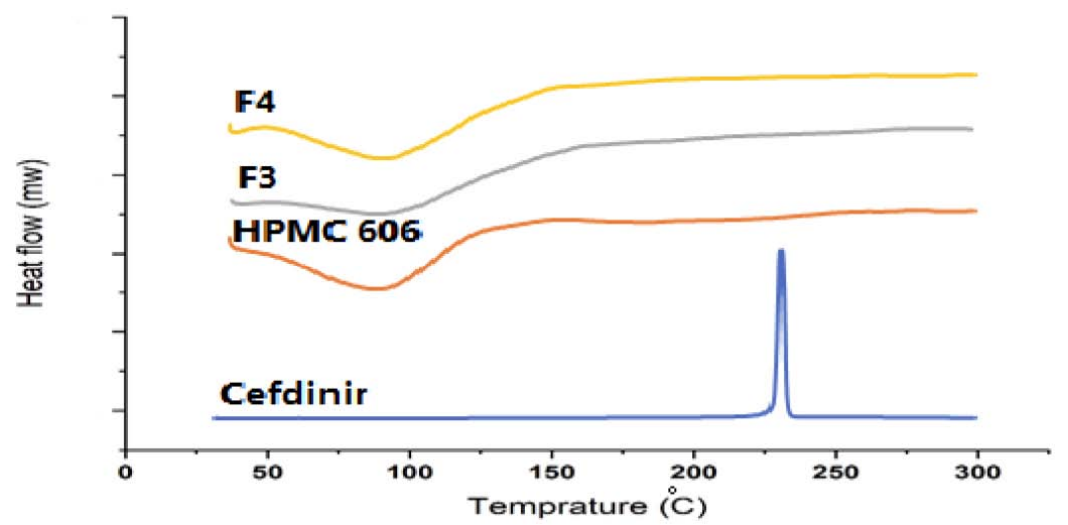

Figure 8: DSC thermograms of Cefdinir, HPMC, F3, and F4. 


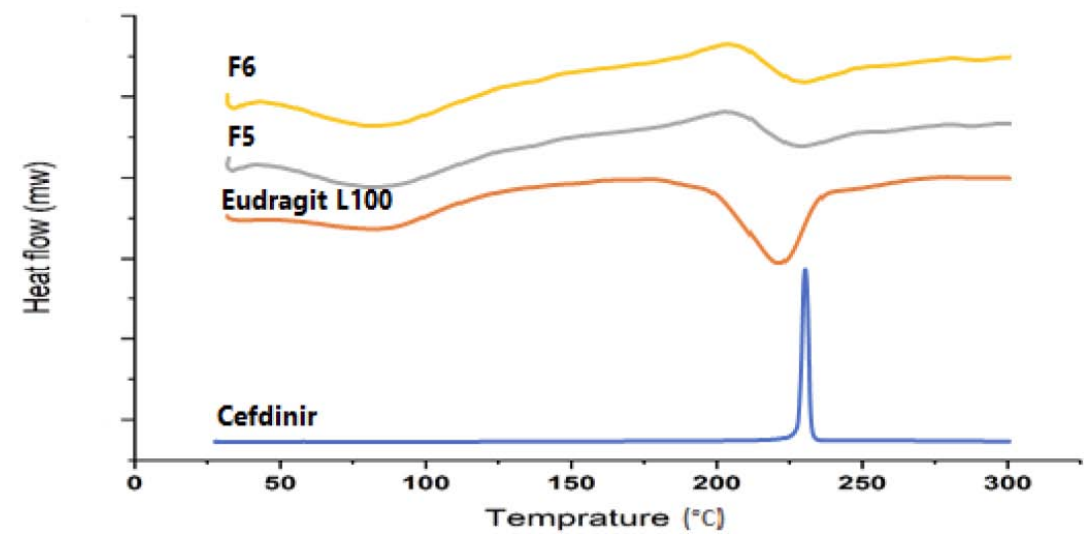

Figure 9: DSC thermograms of Cefdinir, Eudragit L100, F5, and F6.

peak appeared at a higher temperature with an onset $195.61{ }^{\circ} \mathrm{C}$, endset of $236.64{ }^{\circ} \mathrm{C}$, which may be due to the glass transition of the polymer [48].

On the other hand, DSC thermograms of different $\mathrm{pH}_{\mathrm{M}^{-}}$ SDs are also shown in "Figures 7, 8, and 9". However, there is no exothermic peak observed at the melting point of Cefdinir in the thermograms of prepared solid dispersions. The absence of a peak indicates complete conversion into an amorphous form [49], [50].

\subsection{Powder X-Ray Diffraction}

The PXRD pattern of pure cefdinir "Figure 10" showed characteristic peaks at $5.85^{\circ}, 11.7^{\circ}, 16.1^{\circ}, 21.15^{\circ}$, $22.25^{\circ}, 24.4^{\circ}, 26.2^{\circ}$, and $28.8^{\circ}$ of $2 \theta$ [4].
On the other hand, all $\mathrm{pH}_{\mathrm{M}}$-SDs were characterized by a complete absence of any peaks corresponding to the crystalline form of cefdinir "Figure 10".

According to FTIR, DSC, and PXRD results, they suggested the conversion of the crystalline cefdinir into amorphous salt, and they showed a good correlation with each other.

\subsection{Drug Release Studies}

The dissolution studies for different $\mathrm{pH}_{\mathrm{M}}-\mathrm{SD}$ formulations were performed in $\mathrm{HCl}$ buffer $(\mathrm{pH} 1.2)$, acetate buffer $(\mathrm{pH} 4.5)$, and phosphate buffer $(\mathrm{pH} \mathrm{6.8)}$ fluids. As shown in "Figure 11" Cefdinir (pure drug) and its SDs (F1 to F6) showed relatively higher dissolution at $\mathrm{pH} 6.8$ "Figure 11c" compared to $\mathrm{pH} 1.2$ and pH 4.5

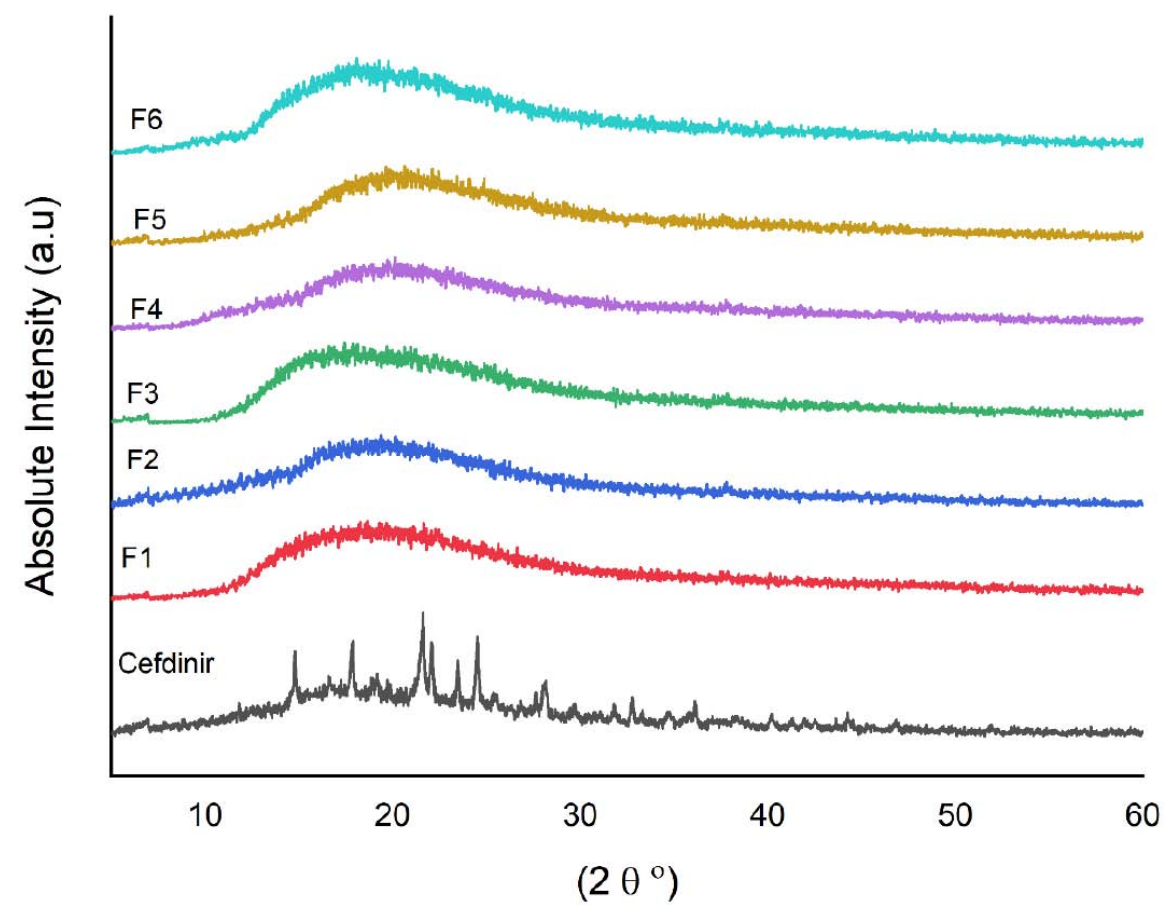

Figure 10: Comparison of PXRD diffractograms of pure cefdinir and its prepared $\mathrm{pH}_{\mathrm{M}}-\mathrm{SDs}$. 

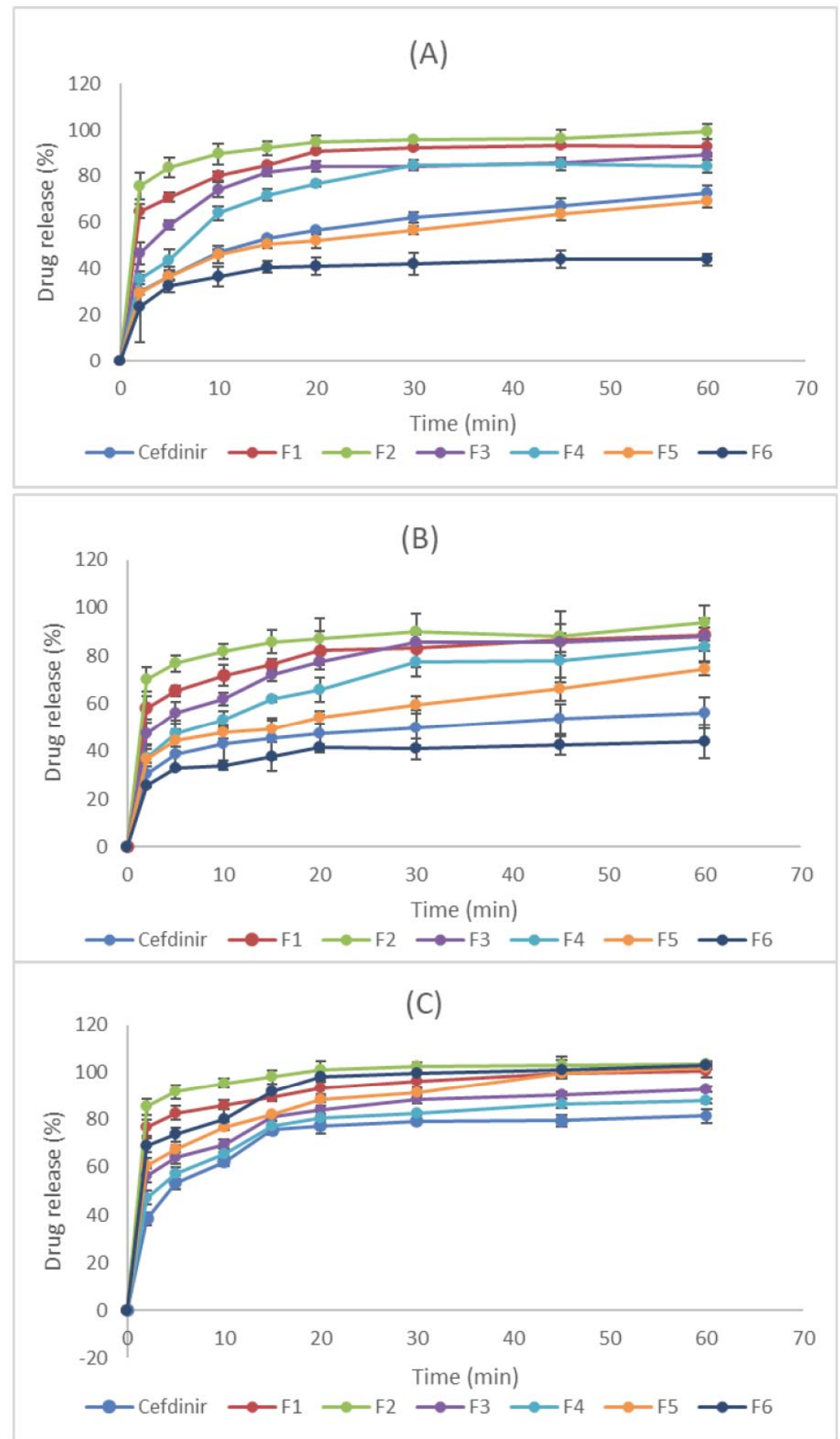

Figure 11: Drug release profile from pure cefdinir and different formulation (from $\mathrm{F} 1$ to $\mathrm{F} 6$ ) in: (A) $\mathrm{HCl} \mathrm{pH} 1.2$ (B) Acetate buffer pH 4.5 (C) Phosphate buffer $\mathrm{pH} 6.8$.

"Figure 11a, 11b", due to the poor solubility of cefdinir at low $\mathrm{pH}$.

\subsubsection{Effect of Different Carriers on the Dissolution of Cefdinir from Solid Dispersions}

Table 3 enlists the dissolution parameters of Cefdinir solid dispersions with various carriers (PVP-K30, HPMC, and Eudragit L100).
It could be also found that PVP-based $\mathrm{pH}_{\mathrm{M}}-\mathrm{SDs}$ showed an enhanced dissolution at all studied media compared to the pure drug at all time points according to two-tailed Student's t-test $(p<0.05)$, especially in phosphate buffer, it was found that the PVP-K30 based SDs (F1 and F2) could reach the highest dissolution rate within $30 \mathrm{~min}$, while the HPMC-based SDs (F3 and F4) exhibited lower drug release (Table 3). This might 
Table 3: Dissolution Parameters of Cefdinir and Various Solid Dispersion Formulations

\begin{tabular}{|c|c|c|c|c|c|}
\hline Formulation & $D P_{5 \min }{ }^{a}$ & $D P_{15 \min }{ }^{a}$ & $D P_{60 \min }{ }^{a}$ & $\% \mathrm{DE}_{10 \min }^{\mathrm{b}}$ & $\% \mathrm{DE}_{30 \text { min }}{ }^{\mathrm{b}}$ \\
\hline & \multicolumn{5}{|c|}{$\mathrm{HCl}$ buffer $\mathrm{pH}=1.2$} \\
\hline Pure drug & 36.64 & 52.94 & 72.73 & 33.91 & 48.54 \\
\hline F1 & 70.77 & 84.73 & 92.86 & 64.51 & 80.44 \\
\hline F2 & 83.73 & 92.07 & 99.33 & 74.79 & 87.4 \\
\hline F3 & 58.77 & 81.81 & 89.38 & 53.73 & 72.79 \\
\hline F4 & 43.59 & 71.81 & 84.29 & 42.32 & 64.71 \\
\hline F5 & 36.59 & 50.81 & 69.33 & 38.85 & 48.59 \\
\hline \multirow[t]{2}{*}{ F6 } & 32.59 & 40.73 & 43.94 & 28.03 & 35.66 \\
\hline & \multicolumn{5}{|c|}{ Acetate buffer $\mathrm{pH}=4.5$} \\
\hline Pure drug & 38.42 & 45.24 & 56.23 & 33.63 & 42.41 \\
\hline F1 & 65.42 & 76.24 & 88.78 & 58.68 & 72.64 \\
\hline F2 & 76.88 & 85.76 & 93.74 & 68.75 & 80.8 \\
\hline F3 & 56.06 & 71.97 & 88.23 & 49.76 & 67.39 \\
\hline F4 & 47.33 & 61.83 & 83.74 & 41.56 & 57.91 \\
\hline F5 & 44.45 & 49.29 & 74.45 & 38.86 & 48.59 \\
\hline \multirow[t]{2}{*}{ F6 } & 32.76 & 37.68 & 43.96 & 28.03 & 35.56 \\
\hline & \multicolumn{5}{|c|}{ Phosphate buffer $\mathrm{pH}=6.8$} \\
\hline Pure drug & 53.53 & 75.59 & 81.41 & 46.57 & 65.86 \\
\hline F1 & 82.76 & 89.63 & 100.80 & 73.78 & 86.07 \\
\hline F2 & 91.76 & 98.14 & 103.54 & 81.86 & 93.92 \\
\hline F3 & 63.98 & 81.19 & 92.79 & 57.11 & 74.13 \\
\hline F4 & 57.37 & 77.26 & 87.71 & 51.09 & 69.29 \\
\hline F5 & 67.34 & 82.01 & 102.21 & 61.31 & 77.85 \\
\hline F6 & 73.63 & 91.65 & 103.264 & 66.84 & 85.38 \\
\hline
\end{tabular}

be due to the increased wettability of the drug caused by PVP-K30, and the changes in the drug crystallinity imparted by the alkalizer [40], the probable reduction in Cefdinir particle size [28], the modulation of microenvironmental $\mathrm{pH}$ surrounding particles [51, 52]. For HPMC-based SDs, although HPMC 606 has a rapid hydration property in the aqueous solution, it showed a relatively higher swelling property during the dissolution test and further retarded the drug release from the $\mathrm{pH}_{\mathrm{M}}-\mathrm{SDs}$ [53].

For eudragit $\mathrm{L} 100$ based $\mathrm{pH}_{\mathrm{M}}-\mathrm{SDs}$, the highest release was observed at $\mathrm{pH} 6.8$, because eudragit $\mathrm{L} 100$ is soluble in intestinal fluid from $\mathrm{pH} 6$ [54]. At $\mathrm{pH} 1.2$ and 4.5 eudragit $\mathrm{L} 100$ is insoluble, but drug release from the eudragit $\mathrm{L} 100$ based $\mathrm{pH}_{\mathrm{M}}-\mathrm{SDs}$ was significantly impacted by the microenvironmental $\mathrm{pH}$ induced by the solubilized drug. Solubilized cefdinir salt or solubilized
$\mathrm{pH}$ modifier (alkalizer: $\mathrm{NaOH}$ ) increased the microenvironment $\mathrm{pH}$ which dissolved the polymer and released the drug slowly even at lower $\mathrm{pH}$ media (1.2 and 4.5) [55]. While at $\mathrm{pH} 6.8 \mathrm{pH}_{\mathrm{M}}-\mathrm{SDs}$ based on eudragit L100 showed dissolution rates higher than $\mathrm{pH}_{\mathrm{M}}$-SDs based on HPMC. As we can see in Figure 11, F5 and F6 showed a significant enhancement in drug release in phosphate buffer $(\mathrm{pH} \mathrm{6.8)}$ at all time points vis-a'-vis F3 and F4 according to Student's t-test $(p<0.05)$.

\subsubsection{Effect of Concentration of the Carriers on the Dissolution of Cefdinir from solid Dispersions}

Table 3 reveals that drug dissolution improved to varying degrees with the rise in the amount of each carrier. In contrast to all other explored carriers, HPMC, at higher carrier concentrations showed rather decreased drug release rates vis-a'-vis pure drug, 
which could be because of the protective viscous layer which had been formed around the drug compact during dissolution [56].

For comparative analysis of all the formulations, \%DE values at two times, representing the early and late phase of dissolution study, were computed. The \%DE values in the initial time period of dissolution study (e.g., \%DE10 min) provide comparative information for very fast releasing formulations, whereas, \%DE30 min values furnish relative information about both fast and slow releasing formulations.

The value of \%DE10 min for pure drug $(33.91,33.63$, and 46.57 in $\mathrm{HCl}$ buffer, acetate buffer, and phosphate buffer, respectively) was enhanced from miniscule (42.32, 41.56, and 51.09 for HPMC system) to very high $(74.79,68.75$, and 81.86 for PVP-k30 system) at $1: 2 \mathrm{w} / \mathrm{w}$ drug: carrier ratio.

However, the ratio of drug to carrier has been shown to have an effect on drug release. For $\mathrm{pH}_{\mathrm{M}}$-SDs based on $\mathrm{PVP}-\mathrm{K} 30$, the more carrier present, the more a drug is converted into the amorphous form, which leads to greater drug release [21,57]. And this was obvious in drug release studies "Figure 11". F2 showed an enhanced dissolution rate in comparison with $\mathrm{F} 1$ at (2, 5,10 , and 15 mins) according to a two-tailed Student's t-test $(p<0.05)$. This result was in agreement with a previous study which showed that the drug dissolution from $\mathrm{pH}_{\mathrm{M}}$-SDs increased when increasing the drug/carrier ratio and stopped increasing when the ratio reached above 1:2 [58].

Table 4: Statistical Parameters of Various Formulations Obtained after Fitting the Drug Release Data to Various Release Kinetic Models

\begin{tabular}{|c|c|c|c|c|c|c|c|c|c|c|c|}
\hline \multirow[t]{4}{*}{ Formulation } & \multicolumn{11}{|c|}{ Mathematical models for drug release kinetics } \\
\hline & \multicolumn{2}{|c|}{ Zero order } & \multicolumn{2}{|c|}{ First order } & \multicolumn{2}{|c|}{ Higuchi } & \multicolumn{2}{|c|}{ Hixson-Crowell } & \multicolumn{3}{|c|}{ Korsemeyer-Peppas } \\
\hline & \multicolumn{11}{|c|}{$\mathrm{HCl}$ buffer $\mathrm{pH}=1.2$} \\
\hline & Slope & $r^{2}$ & Slope & $r^{2}$ & Slope & $r^{2}$ & Slope & $r^{2}$ & Slope & $r^{2}$ & $\mathbf{n}$ \\
\hline Cefdinir & 0.669 & 0.861 & 0.07 & 0.794 & 11.1 & 0.436 & 0.01 & -0.623 & 25.58 & 0.992 & 0.257 \\
\hline F1 & 0.434 & 0.647 & 0.24 & 0.619 & 16.5 & -5.93 & 0.03 & -4.923 & 61.33 & 0.950 & 0.113 \\
\hline $\mathbf{F} 2$ & 0.315 & 0.669 & 0.34 & 0.696 & 3.29 & 0.832 & 0.03 & -16.64 & 74.11 & 0.952 & 0.075 \\
\hline F3 & 0.564 & 0.579 & 0.13 & 0.880 & 6.05 & 0.758 & 0.03 & -0.856 & 47.60 & 0.886 & 0.166 \\
\hline F4 & 0.761 & 0.648 & 0.07 & 0.909 & 8.02 & 0.820 & 0.02 & 0.383 & 34.54 & 0.922 & 0.241 \\
\hline F5 & 0.601 & 0.964 & 0.11 & 0.475 & 5.84 & 0.961 & 0.01 & -1.961 & 26.98 & 0.986 & 0.233 \\
\hline \multirow[t]{2}{*}{ F6 } & 0.262 & 0.694 & 0.23 & 0.729 & 2.78 & 0.844 & 0.01 & -1.334 & 25.36 & 0.932 & 0.156 \\
\hline & \multicolumn{11}{|c|}{ Acetate buffer $\mathrm{pH}=4.5$} \\
\hline Cefdinir & 0.372 & 0.822 & 0.16 & 0.710 & 3.73 & 0.938 & 0.01 & -5.570 & 28.51 & 0.988 & 0.169 \\
\hline F1 & 0.465 & 0.779 & 0.23 & 0.601 & 4.72 & 0.897 & 0.02 & -4.159 & 54.10 & 0.979 & 0.125 \\
\hline F2 & 0.314 & 0.709 & 0.33 & 0.621 & 3.23 & 0.855 & 0.03 & -14.47 & 67.91 & 0.966 & 0.078 \\
\hline F3 & 0.658 & 0.774 & 0.09 & 0.669 & 6.68 & 0.909 & 0.02 & -0.566 & 42.10 & 0.967 & 0.191 \\
\hline F4 & 0.739 & 0.848 & 0.08 & 0.726 & 7.35 & 0.955 & 0.02 & -0.200 & 32.00 & 0.981 & 0.240 \\
\hline F5 & 0.591 & 0.964 & 0.15 & 0.475 & 5.60 & 0.966 & 0.01 & -1.961 & 29.88 & 0.977 & 0.212 \\
\hline \multirow[t]{2}{*}{ F6 } & 0.253 & 0.694 & 0.19 & 0.726 & 2.61 & 0.844 & 0.01 & -8.884 & 25.12 & 0.948 & 0.142 \\
\hline & \multicolumn{11}{|c|}{ Phosphate buffer $\mathrm{pH}=6.8$} \\
\hline Cefdinir & 0.583 & 0.581 & 0.11 & 0.902 & 6.26 & 0.762 & 0.02 & -0.510 & 40.28 & 0.870 & 0.190 \\
\hline F1 & 0.380 & 0.838 & 0.35 & 0.505 & 3.79 & 0.954 & 0.03 & -13.58 & 72.05 & 0.993 & 0.084 \\
\hline F2 & 0.258 & 0.666 & 0.41 & 0.635 & 2.71 & 0.835 & 0.03 & -33.83 & 83.45 & 0.957 & 0.057 \\
\hline F3 & 0.570 & 0.754 & 0.18 & 0.611 & 5.82 & 0.895 & 0.03 & -1.808 & 51.41 & 0.958 & 0.152 \\
\hline F4 & 0.610 & 0.703 & 0.13 & 0.764 & 6.33 & 0.861 & 0.02 & -0.777 & 44.47 & 0.948 & 0.178 \\
\hline F5 & 0.674 & 0.865 & 0.18 & 0.551 & 6.68 & 0.963 & 0.03 & -1.512 & 53.29 & 0.992 & 0.162 \\
\hline F6 & 0.559 & 0.724 & 0.22 & 0.512 & 5.74 & 0.867 & 0.03 & -3.282 & 62.45 & 0.938 & 0.131 \\
\hline
\end{tabular}


Therefore, in the presence of an alkalizer, a smaller amount of $\mathrm{pH}$ modifier might still provide a high degree of saturation solubility in the $\mathrm{pH}_{\mathrm{M}}$-SD formulation [59]. This phenomenon might be related to the process of forming the solid dispersions; the crystalline structure of the drug and alkalizer were converted to the amorphous state, resulting in an increased dissolution rate of the drug. Obviously, adding $\mathrm{NaOH}$ to SDs enhanced the Cefdinir dissolution rate [58].

For weakly acidic drugs, such as Cefdinir, including an alkalizer as a $\mathrm{pH}$ modifier in the solid dispersion can enhance the drug release. The $\mathrm{pH}$ modifier achieves this by increasing the micro-environment $\mathrm{pH}$, which is described as the $\mathrm{pH}$ of the saturated solution in the environment immediately surrounding the drug particles [20]. Whereas for HPMC-based $\mathrm{pH}_{\mathrm{M}^{-}} \mathrm{SD}, \mathrm{F} 4$ showed a lower dissolution rate in comparison with $\mathrm{F} 3$ at time points $(2,5,10,15$, and 20 mins) according to two-tailed Student's t-test $(p<0.05)$. This can be explained by the fact that HPMC is a water-soluble polymer, but it formed a protective viscous layer around the drug compact during dissolution [56]. It is likely that drug diffusion through the HPMC layer and erosion of the latter affect drug release; consequently, it will take some time for the drug to be released from solid dispersions containing large amounts of HPMC, but it will not influence the dissolution endpoint as also observed in the current study $[56,60]$.

Maximum values of various dissolution parameters observed for PVP-K30 formulation (F2) construe attainment of the very high rate of drug dissolution, comparable to that obtained for formulations.

\subsection{Mathematical Modeling of Release Kinetics}

Table 4 enlists the regression parameters obtained after fitting various release kinetic models to the in vitro dissolution data.

Based on the determination coefficient $\left(r^{2}\right)$, the Korsmeyer-Peppas model is the function that best fits the dissolution data of Cefdinir and prepared $\mathrm{pH}_{\mathrm{M}}-\mathrm{SDs}$ at different $\mathrm{pHs}$.

Overall, the values of diffusional exponent ' $n$ ', obtained from the slopes of the fitted Korsmeyer-Peppas model, ranged between 0.057 and 0.257 . all the solid dispersions tended to exhibit Fickian diffusional characteristics, as the corresponding values of $n$ were lower than the standard value for declaring Fickian release behavior, i.e., 0.4500 [30].

\section{CONCLUSION}

In this study, a $\mathrm{pH}_{\mathrm{M}}-\mathrm{SD}$ was used to increase the dissolution rate of a poorly water-soluble weakly acidic drug, such as Cefdinir, in a $\mathrm{pH}$-dependent manner. Among the three types of polymers, PVP-K30 based $\mathrm{pH}_{\mathrm{M}}$-SDs significantly increased the drug dissolution in media with different $\mathrm{pH}(1.2,4.5$, and 6.8). The major contributing factors for enhancing the dissolution in SD containing alkalizer were the modulation of $\mathrm{pH}_{\mathrm{M}}$ and the formation of an amorphous state through molecular interactions, which was verified using FTIR, SEM, DSC, and PXRD analyses. In fact, the system also might fit for the other poorly water-soluble weakly acidic drugs because of their similar physical characters.

\section{ACKNOWLEDGEMENT}

R. Al-Nuss acknowledges the Diamond pharmaceutical industry for providing research materials. The work was carried out in the Faculty of Pharmacy (Damascus University) and was supported by Atomic Energy Authority (Syria).

\section{FUNDING}

R. Al-Nuss acknowledges Damascus University for funding this research.

\section{AUTHORS' CONTRIBUTION}

The author confirms sole responsibility for the following: study conception and design, data collection, analysis and interpretation of results, and manuscript preparation.

\section{CONFLICT OF INTEREST}

The authors declare that they have no conflict of interest.

\section{STATEMENT OF HUMAN AND ANIMAL RIGHTS}

This article does not contain any studies with human and animal subjects performed by any of the authors.

\section{REFRENCES}

[1] Wise R, Andrews JM, Thbornber D. The in-vitro activity of cefdinir (FK482), a new oral cephalosporin. J Antimicrob Chemother 1991; 28(2): 239-48. https://doi.org/10.1093/jac/28.2.239

[2] Guay DRP. Cefdinir: An advanced-generation, broadspectrum oral cephalosporin. Clin Ther 2002; 24(4): 473-89. https://doi.org/10.1016/S0149-2918(02)85125-6

[3] Perry CM, Scott LJ. Cefdinir: a review of its use in the management of mild-to-moderate bacterial infections. Drugs 2004; 64(13): 1433-64.

https://doi.org/10.2165/00003495-200464130-00004 
[4] Aleem O, Kuchekar B, Pore $Y$, Late S. Effect of $\beta$ cyclodextrin and hydroxypropyl $\beta$-cyclodextrin complexation on physicochemical properties and antimicrobial activity of cefdinir. J Pharm Biomed Anal 2008; 47(3): 535-40.

https://doi.org/10.1016/j.jpba.2008.02.006

[5] Bassi P, Kaur G. pH modulation: a mechanism to obtain $\mathrm{pH}-$ independent drug release. Expert Opin Drug Deliv 2010; 7: 845-57.

https://doi.org/10.1517/17425247.2010.491508

[6] Sawant KK, Patel MH, Patel K. Cefdinir nanosuspension for improved oral bioavailability by media milling technique: formulation, characterization and in vitro-in vivo evaluations. Drug Dev Ind Pharm 2015; November: 1-11. Available from: https://pubmed.ncbi.nlm.nih.gov/26548349/

[7] Patil OA, et al. Formulation optimization and evaluation of Cefdinir nanosuspension using 23 Factorial design. Marmara Pharm J 2018; 22(4): 587-98. https://doi.org/10.12991/irp.2018.101

[8] Park J, et al. Preparation and pharmaceutical characterization of amorphous cefdinir using spray-drying and SAS-process. Int J Pharm 2010; 396: 239-45.

https://doi.org/10.1016/j.ijpharm.2010.06.032

[9] Morina D, Sessevmez M, Sinani G, Mülazımoğlu L, Cevher E. Oral tablet formulations containing cyclodextrin complexes of poorly water soluble cefdinir to enhance its bioavailability. J Drug Deliv Sci Technol 2020; 57: 101742 https://doi.org/10.1016/j.jddst.2020.101742

[10] Chhayani RL, Chhayani RB, Patel D, Borkhataria CH. Development and characterization of self- microemulsifying drug delivery system for improvement of bioavailability of Cefdinir. JPMC 2016; 2(1): 57-83. https://doi.org/10.21088/jpmc.2395.6615.2116.7

[11] Cho HJ, et al. Cefdinir solid dispersion composed of hydrophilic polymers with enhanced solubility, dissolution, and bioavailability in rats. Molecules 2017; 22, 280: 1-14. https://doi.org/10.3390/molecules22020280

[12] Jain S, Jain S, Mishra A, Garg G, Modi RK. Formulation and characterization of fast disintegrating tablets containing Cefdinir solid dispersion. Int J Pharm Life Sci 2012; 3(12): 2190-99.

[13] Maraie NK, Alhamadany AT, Radhi AA. Efficacy of combination solid dispersion technology on dissolution performance of nalidixic acid and cefdinir. Asian J Pharm Clin Res 2017; 10 (4): 394-01. https://doi.org/10.22159/ajpcr.2017.v10i4.16913

[14] Prathibha B, Reddy DV, Reddy DS. Formulation and evaluation of once a day tablet of cefdinir. Int $\mathrm{J}$ Pharm Technol 2014; 5(4): 115-30.

[15] Lakshmanarao $\mathrm{P}$ et al., Enhancement of solubility and dissolution rate of Cefdinir using solid dispersions. Indo Am j pharm res 2017; 4(3): 747-53.

[16] Kumar P, Kumar S. Physicochemical characterization of solid dispersions of Cefdinir with PVP K-30 and PEG 4000. Int J Pharm Sci Nanotech 2010; 3(2) https://doi.org/10.37285/ijpsn.2010.3.2.8

[17] Vasconcelos T, Sarmento B, Costa P. Solid dispersions as strategy to improve oral bioavailability of poor water soluble drugs. Drug Discov Today 2007; 12(23-24): 1068-75. https://doi.org/10.1016/j.drudis.2007.09.005

[18] Heo MY, Piao ZZ, Kim TW, Cao QR, Kim A, Lee BJ. Effect of solubilizing and microemulsifying excipients in polyethylene glycol 6000 solid dispersion on enhanced dissolution and bioavailability of ketoconazole. Arch Pharm Res 2005; 28(5): 604-11.

https://doi.org/10.1007/BF02977766

[19] Paudel A, Worku ZA, Meeus J, Guns S, Van Den Mooter G. Manufacturing of solid dispersions of poorly water soluble drugs by spray drying: Formulation and process considerations. Int J Pharm 2013; 453(1): 253-84. https://doi.org/10.1016/j.ijpharm.2012.07.015
[20] Tran PHL, Tran HTT, Lee BJ. Modulation of microenvironmental $\mathrm{pH}$ and crystallinity of ionizable telmisartan using alkalizers in solid dispersions for controlled release. J Control Release 2008; 129(1): 59-65.

https://doi.org/10.1016/j.jconrel.2008.04.001

[21] Tran PHL, Tran TTD, Lee KH, Kim DJ, Lee BJ. Dissolutionmodulating mechanism of $\mathrm{pH}$ modifiers in solid dispersion containing weakly acidic or basic drugs with poor water solubility. Expert Opin Drug Deliv 2010; 7(5): 647-61. https://doi.org/10.1517/17425241003645910

[22] Baka E, Comer JEA, Takács-Novák K. Study of equilibrium solubility measurement by saturation shake-flask method using hydrochlorothiazide as model compound. J Pharm Biomed Anal 2008; 46(2): 335-41. https://doi.org/10.1016/j.jpba.2007.10.030

[23] Shah PB, Pundarikakshudu K. UV spectroscopic and colorimetric methods for the estimation of cefdinir in capsule dosage forms. Indian J Pharm Sci 2004; 66: 665-67.

[24] Al-Badr AA, Alasseiri FA. Cefdinir. In: Profiles of Drug Substances, Excipients and Related Methodology Elsevier Inc. 2014; 39: 41-112.

https://doi.org/10.1016/B978-0-12-800173-8.00002-7

[25] Muqtader $\mathrm{M}$, et al. Development of spray-dried amorphous solid dispersions of tadalafil using glycyrrhizin for enhanced dissolution and aphrodisiac activity in male rats. Saudi Pharm J 2020; 28(12): 1817-26. https://doi.org/10.1016/j.jsps.2020.11.007

[26] de Waard $H$, Hinrichs WLJ, Visser MR, Bologna C, Frijlink $\mathrm{HW}$. Unexpected differences in dissolution behavior of tablets prepared from solid dispersions with a surfactant physically mixed or incorporated. Int J Pharm 2008; 349(1-2): 66-73.

https://doi.org/10.1016/j.ijpharm.2007.07.023

[27] Khan KA. The concept of dissolution efficiency. J Pharm Pharmacol 1975; 27(1): 48-49.

https://doi.org/10.1111/j.2042-7158.1975.tb09378.x

[28] Ahuja N, Katare OP, Singh B. Studies on dissolution enhancement and mathematical modeling of drug release of a poorly water-soluble drug using water-soluble carriers. Eur J Pharm Biopharm 2007; 65(1): 26-38. https://doi.org/10.1016/j.ejpb.2006.07.007

[29] Higuchi T. Mechanism of sustained-action medication Theoretical analysis of rate of release of solid drugs dispersed in solid matrices. J Pharm Sci 1963; 52(12): 114549. https://doi.org/10.1002/jps.2600521210

[30] Korsmeyer RW, Gurny R, Doelker E, Buri P, Peppas NA. Mechanisms of solute release from porous hydrophilic polymers. Int J Pharm 1983; 15(1): 25-35. https://doi.org/10.1016/0378-5173(83)90064-9

[31] Ritschel WA. Biopharmaceutic and pharmacokinetic aspects in the design of controlled release peroral drug delivery systems. Drug Dev Ind Pharm 1989; 15: 1073-103. https://doi.org/10.3109/03639048909043666

[32] Zhang $\mathrm{Y}$, et al. DDSolver: An add-in program for modeling and comparison of drug dissolution profiles. AAPS J 2010; 12(3): 263-71.

https://doi.org/10.1208/s12248-010-9185-1

[33] Lepsy CS, Guttendorf RJ, Kugler AR, Smith DE. Effects of organic anion, organic cation, and dipeptide transport inhibitors on cefdinir in the isolated perfused rat kidney. Antimicrob Agents Chemother 2003; 47(2): 689-96. https://doi.org/10.1128/AAC.47.2.689-696.2003

[34] Smeets A, Koekoekx R, Clasen C, Van Den Mooter G. Amorphous solid dispersions of darunavir: Comparison between spray drying and electrospraying. Eur $\mathrm{J}$ Pharm Biopharm 2018. https://doi.org/10.1016/j.ejpb.2018.06.021 
[35] Kwon J, Giri BR, Song ES, Bae J, Lee J, Kim DW. Spraydried amorphous solid dispersions of atorvastatin calcium for improved supersaturation and oral bioavailability. Pharmaceutics 2019; 11(9).

https://doi.org/10.3390/pharmaceutics11090461

[36] Shinde Sunita S, Patil Manisha V, Amol Shete S, Disouza JI, Pranit A. Solid dispersions of poorly water soluble drug using spray drying technique. Int J Drug Deliv 2013; 5(3): 323-30.

[37] El Maghraby G, Elsergany R. Fast disintegrating tablets of nisoldipine for intra-oral administration. Pharm Dev Technol 2014; 19(6): 641-50. https://doi.org/10.3109/10837450.2013.813543

[38] Mohdavinia GR, Ettehadi S, Amini M, and Sabzi M. Synthesis and characterization of hydroxypropyl methylcellulose-g-poly(acrylamide)/LAPONITE $® \quad$ RD nanocomposites as novel magnetic- and $\mathrm{pH}$ sensitive carriers for controlled drug release. RSC Adv 2015; 5: 4451623.

\section{https://doi.org/10.1039/C5RA03731J}

[39] Jena Pk, Singh S, Prajapati B, Nareshkumar G, Mehta T, Seshadri S. Impact of Targeted Specific Antibiotic Delivery for Gut Microbiota Modulation on High-Fructose-Fed Rats. Appl Biochem and Biotechnol 2014; 172(8): 3810-26. https://doi.org/10.1007/s12010-014-0772-y

[40] Telang C, Mujumdar S, and Mathew M. Improved Physical Stability of Amorphous State through Acid Base Interactions. J Pharm Sci 2009; 98(6): 2149-59. https://doi.org/10.1002/jps.21584

[41] Server NE, and Law D. WO2005100368A2. 2006.

[42] Cabri W, et al. Cefdinir: A comparative study of anhydrous vs. monohydrate form. Microstructure and tabletting behaviour. Eur J Pharm Biopharm 2006; 64(2): 212-21. https://doi.org/10.1016/j.ejpb.2006.05.007

[43] Chan S, Chung Y, Cheah X, Tan EY, Quah J. The characterization and dissolution performances of spray dried solid dispersion of Ketoprofen in hydrophilic carriers. Asian J Pharm Sci 2015; 10(5): 372-85. https://doi.org/10.1016/j.ajps.2015.04.003

[44] Turner DT., Schartz A. The glass transition temperature of poly (n-vinyl pyrrolidone) by differential scanning calorimetry, Polymers 1985; 26: 757-62.

https://doi.org/10.1016/0032-3861(85)90114-4

[45] Al-mogherah Al, Abbas M, Abdelazeem M. Optimization and evaluation of venlafaxine hydrochloride fast dissolving oral films. Saudi Pharm J 2020; 28(11): 1374-82. https://doi.org/10.1016/j.jsps.2020.09.001

[46] Ammar HO, Ghorab MM, Mahmoud AA, Noshi SH. Formulation of risperidone in floating microparticles to alleviate its extrapyramidal side effects. Futur $\mathrm{J}$ Pharm Sci 2016; 2(2): 43-59.

https://doi.org/10.1016/j.fjps.2016.08.001

[47] Amer MA, Essa EA, Donia AA, El Maghraby GM. Development and evaluation of liquid oral controlled release systems for Losartan potassium. J Appl Pharm Sci 2019; 9(8): 86-93.

https://doi.org/10.7324/JAPS.2019.90812

[48] Yang YY, Zhang M, Wang K, Yu DG. pH-sensitive polymer nanocoating on hydrophilic composites fabricated using modified coaxial electrospraying. Mater Lett 2018; 227: 9396.

https://doi.org/10.1016/j.matlet.2018.05.063
[49] Jha DK, Shah DS, Amin PD. Thermodynamic aspects of the preparation of amorphous solid dispersions of Naringenin with enhanced dissolution rate. Int J Pharm 2020; 583, no. January, p. 119363.

https://doi.org/10.1016/j.jpharm.2020.119363

[50] Fujimori M, Kadota K, Shimono K, Shirakawa $Y$, Sato H, Tozuka Y. Enhanced solubility of quercetin by forming composite particles with transglycosylated materials. J Food Eng 2015; 149: 248-54. https://doi.org/10.1016/j.jfoodeng.2014.10.010

[51] Onoue $\mathrm{S}$, et al. Improved dissolution and pharmacokinetic behavior of dipyridamole formulation with microenvironmental $\mathrm{pH}$-modifier under hypochlorhydria. Int $\mathrm{J}$ Pharm 2012; 426(1-2): 61-66. https://doi.org/10.1016/j.ijpharm.2012.01.014

[52] Ha NS, Tran TTD, Tran PHL, Park JB, Lee BJ. Dissolutionenhancing mechanism of alkalizers in poloxamer-based solid dispersions and physical mixtures containing poorly watersoluble valsartan. Chem Pharm Bull 2011; 59(7): 844-50. https://doi.org/10.1248/cpb.59.844

[53] Xu WJ et al., Enhanced dissolution and oral bioavailability of valsartan solid dispersions prepared by a freeze-drying technique using hydrophilic polymers. Drug Deliv 2016; 23(1): 41-48.

https://doi.org/10.3109/10717544.2014.903012

[54] Rowe RC, Sheskey PJ, Quinn ME. Handbook of Pharmaceutical Excipients, $6^{\text {th }}$ edition, Pharmaceutical Press. 2009 p. 525- 33

[55] Liu X, Ma M, Kun E, Guo X, Yu Z, Zhang Z. Influence of lidocaine forms (salt vs. freebase) on properties of drugeudragit $\circledast$ L $100-55$ extrudates prepared by reactive melt extrusion. Int J Pharm 2018; 547(1-2): 291-02. https://doi.org/10.1016/j.ijpharm.2018.06.009

[56] Velasco MV, Ford JL, Rowe P, Rajabi-Siahboomi AR. Influence of drug:hydroxypropylmethylcellulose ratio, drug and polymer particle size and compression force on the release of diclofenac sodium from HPMC tablets. J Control Release 1999; 57(1): 75-85. https://doi.org/10.1016/S0168-3659(98)00110-2

[57] Fousteris E, Tarantili PA, KaravasE, Bikiaris D. Poly(vinyl pyrrolidone)-poloxamer-188 solid dispersions prepared by hot melt extrusion: Thermal properties and release behavior. J Therm Anal Calorim 2013; 113(3): 1037-47. https://doi.org/10.1007/s10973-012-2885-2

[58] Yang $\mathrm{M}$, et al. Microenvironmental $\mathrm{pH}$-modified solid dispersions to enhance the dissolution and bioavailability of poorly water-soluble weakly basic GT0918, a developing anti-prostate cancer drug: Preparation, characterization and evaluation in vivo. Int J Pharm 2014; 475(1-2): 97-109. https://doi.org/10.1016/j.ijpharm.2014.08.047

[59] Marasini $\mathrm{N}$, et al. Fabrication and evaluation of $\mathrm{pH}$ modulated solid dispersion for telmisartan by spray-drying technique. Int J Pharm 2013; 441(1-2): 424-32.

https://doi.org/10.1016/j.ijpharm.2012.11.012

[60] Kayaert P, Van den Mooter G. An investigation of the adsorption of hydroxypropylmethyl cellulose $29105 \mathrm{mPa} \mathrm{s}$ and polyvinylpyrrolidone K90 around Naproxen nanocrystals. J Pharm Sci 2012; 101: 3916-23. https://doi.org/10.1002/jps.23267 